\title{
PERILAKU MAHASISWA FAKULTAS KEDOKTERAN PROGRAM \\ STUDI KEDOKTERAN UMUM TAHAP PROFESI DAN PROGRAM STUDI KEPERAWATAN TERHADAP HIV/AIDS DI FAKULTAS KEDOKTERAN UNIVERSITAS SAM RATULANGI MANADO
}

\author{
${ }^{1}$ Jennifer Lintang \\ ${ }^{2}$ Jane Pangemanan \\ ${ }^{2}$ Henry M.F. Palandeng
}

\author{
${ }^{1}$ Kandidat Skripsi Fakultas Kedokteran Universitas Sam Ratulangi Manado \\ ${ }^{2}$ Bagian Ilmu Kesehatan Masyarakat Fakultas Kedokteran Universitas Sam Ratulangi Manado \\ Email: ladylintang@rocketmail.com
}

\begin{abstract}
Cumulative number of AIDS cases in the epidemic of AIDS cases in Indonesia is a serious health problem facing the society. This study aimed to find a description of the behaviors of the students of the General Medicine Study Program in the profesion stage and of the Nursing Study Program of Medical Faculty, Sam Ratulangi University against HIV/AIDS. Data were collected using questionnaires. The questionnaires were related to the knowledge, attitudes, and actions of the students against HIV/AIDS. The results showed that most of the students of both study programs had very good knowledge about HIIV/AIDS, good attitudes, and good enough actions against HIV/AIDS. Conclusion: In general, students of the General Medicine Study Program in the profesion stage and of the Nursing Study Program of Medical Faculty, Sam Ratulangi University had good behaviour against HIV/AIDS.
\end{abstract}

Keywords: behavior, medical students, HIV/AIDS.

\begin{abstract}
Abstrak: Jumlah kumulatif kasus AIDS pada kasus epidemik di Indonesia, AIDS merupakan masalah kesehatan serius yang dihadapi masyarakat. Tujuan penelitian ini adalah mencari gambaran perilaku mahasiswa Fakultas Kedokteran Program Studi Kedokteran Umum tahap profesi dan Program Studi Keperawatan terhadap HIV/AIDS di Fakultas Kedokteran Universitas Sam Ratulangi. Data dikumpulkan melalui kuesioner, yang meliputi pengetahuan, sikap, dan tindakan mahasiswa terhadap HIV/AIDS. Hasil penelitian memperlihatkan bahwa sebagian besar mahasiswa Fakultas Kedokteran tahap profesi dan mahasiswa Program Studi Keperawatan sudah mempunyai tingkat pengetahuan yang baik sekali. Dalam hal sikap, sebagian besar mahasiswa Fakultas Kedokteran tahap profesi dan Program Studi Keperawatan sudah mempunyai sikap yang baik. Dalam hal tindakan, sebagian besar mahasiswa Fakultas Kedokteran tahap profesi sudah mempunyai tindakan yang cukup sedangkan pada mahasiswa Program Studi Keperawatan mempunyai tindakan yang baik. Simpulan: Mahasiswa Fakultas Kedokteran Program Studi Kedokteran Umum tahap profesi dan Program Studi Keperawatan umumnya mempunyai perilaku yang baik terhadap HIV/AIDS.
\end{abstract}

Kata kunci: perilaku, mahasiswa kedokteran, HIV/AIDS.

Acquired Immunodeficiency Syndrome (AIDS) atau sindroma kehilangan kekebalan tubuh adalah sekumpulan gejala penyakit yang menyerang tubuh manusia sesudah sis-tem kekebalan tubuhnya di rusak oleh virus HIV.

\section{PATOGENESIS}

Perjalanan infeksi HIV, jumlah limfosit T-CD4, jumlah virus dan gejala klinis melalui tiga fase, yaitu: Fase Infeksi Akut: sindroma infeksi akut selama tiga sampai 
enam minggu, kemudian akan mengalami penurunan setelah terinfeksi HIV. Fase infeksi laten: pada tahun ke-8 setelah terinfeksi HIV akan timbul gejala klinis. Fase infeksi kronis: perjalanan penyakit semakin progresif yang mendorong kearah AIDS. $^{2,3}$

\section{JENIS PENELITIAN}

Metode penelitian yang digunakan deskriptif dengan metode survey menggunakan kuesioner. Variabel penelitian meliputi: karakteristik, pengetahuan, sikap, tindakan, dan sumber informasi tentang HIV responden.

\section{DEFINISI OPERASIONAL}

Perilaku merupakan respon atau reaksi seseorang terhadap stimulus (rangsangan dari luar) pada masalah HIV/AIDS. ${ }^{4} \mathrm{Pe}$ ngetahuan merupakan hasil dari tahu, yang merupakan domain yang sangat penting untuk terbentuknya perilaku seseorang. ${ }^{5}$

Sikap merupakan evaluasi yang dibuat manusia terhadap dirinya sendiri, orang lain dan objek. Sikap disini yang dimaksud sikap terhadap HIV/AIDS. Tindakan seseorang mengenai stimulus, kemudian mengadakan penelitian atau pendapat apa yang telah diketahui untuk dilaksanakan atau dipraktekan.

\section{LOKASI DAN WAKTU PENELITIAN}

Lokasi di lakukan di lingkungan mahasiswa yang berada di RS Prof. Dr.R.D. Kandou dan di lingkungan kampus kleak Fakultas Kedokteran Universitas Sam Ratulangi Manado.

\section{POPULASI DAN SAMPEL}

Populasi yang dipakai dalam penelitian ini adalah populasi terbatas, yaitu mahasiswa Fakultas Kedokteran Universitas Sam Ratulangi program studi kedokteran umum tahap profesi dan program studi keperawatan.

Jumlah populasi total di lokasi penelitian untuk program studi kedokteran umum tahap profesi adalah 500 orang dan program studi keperawatan adalah 382 orang. Jumlah populasi terbatas yang akan diteliti untuk program studi kedokteran umum tahap profesi adalah 350 orang dan program studi keperawatan adalah 255 orang.

\section{CARA PENGUMPULAN DATA}

Data di ambil dari instansi yang berkaitan degan penelitian, dan kepustakaan. Di ambil pada mahasiswa.

\section{ANALISIS DAN PENGOLAHAN DATA}

Kedua data ini tidak dapat diolah secara bersamaan karena responden masingmasing data berbeda-beda, sehingga pengolahan dilakukan secara terpisah. Setelah data terkumpul dan telah ditentukan kodenya, kemudian dilakukan analisis dengan menentukan persentase kognitif dengan persamaan sebagai berikut:

$P=\frac{F}{N} x 100$

Dimana:

$\mathrm{P}=$ Prosentase

$\mathrm{F}=$ Jumlah jawaban benar

$\mathrm{N}=$ Jumlah skor jawaban total

$100=$ Konstanta

Interpretasi persentase tingkat penerapan kognitif dalam penelitian ini dianalisis dengan cara membuat kategori untuk setiap hasil persentasi menggunakan skala penilaian (Sugiyono, 2010), lalu menginterpretasikan persentase data berdasarkan Arikunto (2008), maka diperoleh tabel sebagai berikut:

Tabel 1. Persentase tingkat kognitif penelitian.

\begin{tabular}{ll}
\hline Persentase & Kriteria \\
\hline $81-100 \%$ & Sangat Baik \\
$61-80 \%$ & Baik \\
$41-60 \%$ & Cukup \\
$21-40 \%$ & Kurang \\
$0-20 \%$ & Sangat Kurang \\
\hline
\end{tabular}


Setelah kuesioner responden diperiksa dengan menggunakan persentase kognitif, diperoleh hasil range persentase.

\section{HASIL}

Dalam penelitian ini didapati hasil menurut variabel yang di ukur dan disajikan dalam gambar diagram dan penjelasannya sebagai berikut:

\section{Gambaran umum responden}

\section{Program Studi}

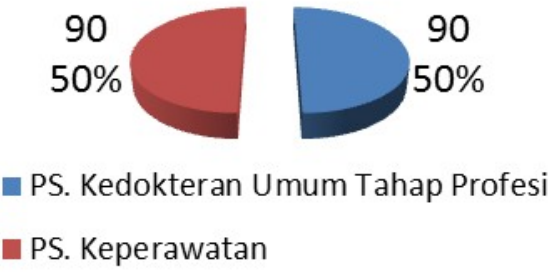

Gambar 1. Distribusi responden menurut program studi.

Gambar 1 di atas menunjukkan bahwa responden dalam penelitian ini masingmasing terbagi atas 90 responden.

\section{Perlakuan Responden}

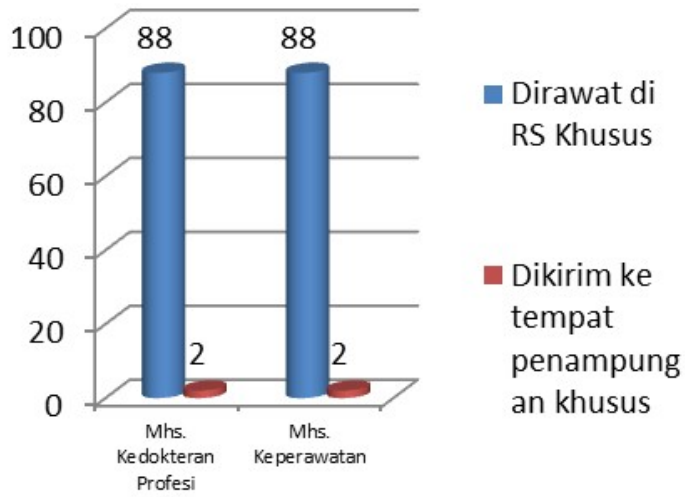

Gambar 2. Distribusi jawaban responden tentang perlakuan terhadap penderita HIV/AIDS.
Gambar 2 di atas menunjukkan bahwa sebagian besar responden baik mahasiswa kedokteran profesi dan mahasiswa keperawatan menjawab bahwa perlakuan terhadap penderita HIV/AIDS adalah dengan merawat di rumah sakit khusus, yaitu mahasiswa kedokteran profesi sebanyak 88 responden $(97,8 \%)$ dan mahasiswa keperawatan sebanyak 88 responden $(97,8 \%)$.

\section{Pengetahuan Responden}

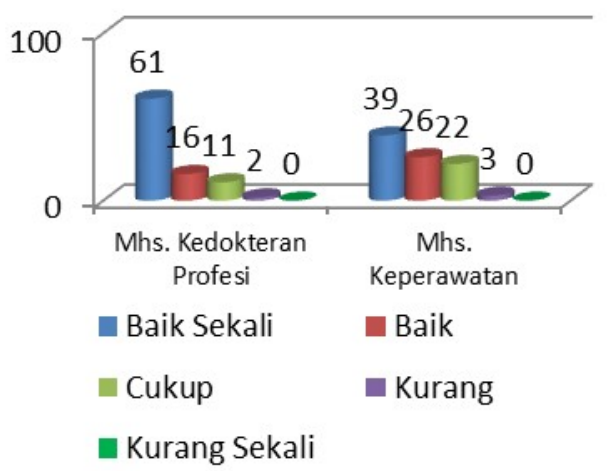

Gambar 3. Distribusi responden tentang pengetahuan HIV/AIDS

Gambar 3 di atas menunjukan bahwa sebagian besar responden baik mahasiswa kedokteran profesi dan mahasiswa keperawatan sudah memiliki pengetahuan yang baik sekali tentang penyakit HIV/AIDS, yaitu mahasiswa kedokteran profesi sebanyak 61 responden $(67,8 \%)$ dan mahasiswa keperawatan sebanyak 39 responden $(43,3 \%)$.

\section{Sikap Responden}

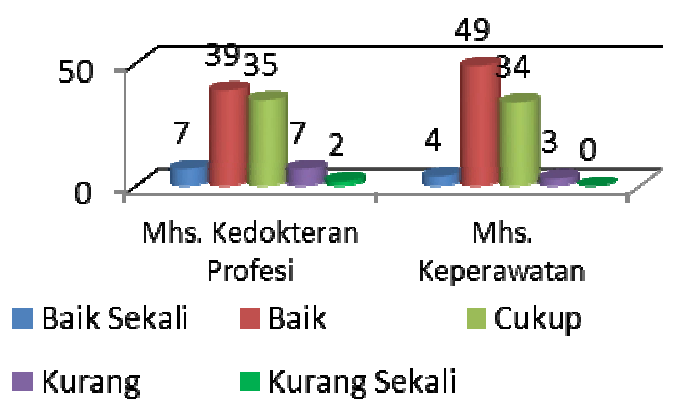

Gambar 4. Distribusi responden tentang sikap terhadap penderita HIV/AIDS. 
Gambar 4 di atas menunjukan bahwa sebagian besar responden baik mahasiswa kedokteran profesi dan mahasiswa keperawatan memiliki sikap yang baik terhadap penderita HIV/AIDS, yaitu mahasiswa kedokteran profesi sebanyak 39 responden $(43,3 \%)$ dan mahasiswa keperawatan sebanyak 49 responden $(54,4 \%)$.

\section{Tindakan Responden}

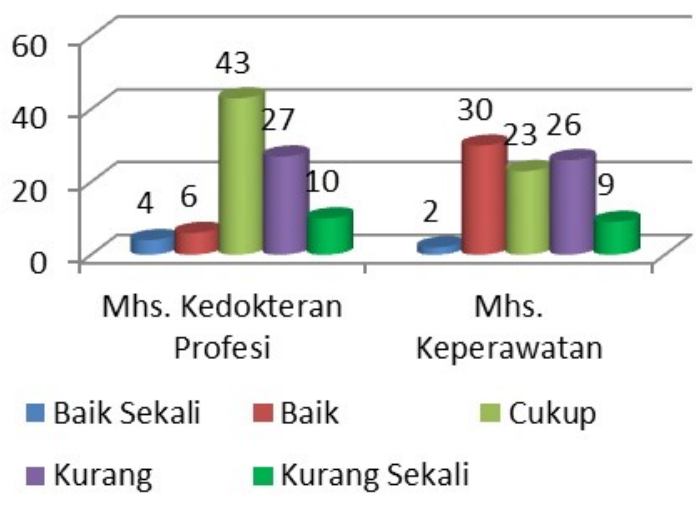

Gambar 5. Distribusi responden tentang tindakan pada penderita HIV/AIDS.

Gambar 5 di atas menunjukan adanya variasi jawaban mahasiswa kedokteran profesi dan mahasiswa keperawatan tentang tindakan pada penderita HIV/AIDS. Pada mahasiswa kedokteran profesi sebagian besar mempunyai tindakan yang cukup yaitu sebanyak 43 responden $(47,8 \%)$ sedangkan mahasiswa keperawatan sebanyak 23 responden $(25,6 \%)$. Tindakan yang baik, pada mahasiswa keperawatan sebanyak 30 responden (33,3\%), sedangkan mahasiswa kedokteran profesi sebanyak enam responden $(6,7 \%)$.

\section{BAHASAN}

Mahasiswa Fakultas kedokteran umum tahap profesi dan mahasiswa program studi keperawatan adalah termasuk pada golongan masyarakat yang sudah memahami dan mengetahui akan penyakit HIV/AIDS. Dalam penelitian ini masing-masing program studi menggunakan responden yang sama banyak.
Pengetahuantentang HIV/AIDS akan menimbulkan respons batin dalam bentuk sikap terhadap penyakit tersebut. Akhirnya rangsangan yang telah diketahui dan disadari sepenuhnya akan menimbulkan respons lebih jauh lagi yaitu berupa tindakan (action) terhadap atau sehubungan dengan stimulus atau objek yang dipahaminya. ${ }^{6}$

\section{Pengetahuan}

Hasil penelitian yang dilakukan, tingkat pengetahuan mahasiswa Fakultas Kedokteran umum tahap profesi dan mahasiswa program studi keperawatan sebagian besar sudah tergolong pada kategori baik sekali. Semakin tinggi tingkat pendidikan formal semakin mudah menyerapin formasi termasuk juga informasi kesehatan, semakin tinggi pula kesadaran untuk berperilaku hidup sehat.

\section{Sikap}

Hasil penelitian tentang sikap, diperoleh bahwa sebagian besar responden mahasiswa kedokteran umum tahap profesi dan mahasiswa program studi keperawatan sudah memiliki sikap yang baik terhadap penderita HIV/AIDS. Sikap mahasiswa yang sudah baik disebabkan karena mereka sudah mengetahui cara pencegahan.

\section{Tindakan}

Hasil penelitian tentang tindakan, pada mahasiswa kedokteran profesi sebagian besar mempunyai tindakan yang cukup. Sedangkan pada mahasiswa keperawatan memiliki tindakan yang baik. Sikap yang positif mampu mengenal dan memilih berbagai objek sehubungan dengan tindakan yang diambil, disebut persepsi. Pada tahap respons terpimpin, mereka dapat melakukan sesuai dengan urutan yang benar. Pada tahap mekanisme, mereka telah dapat melakukan sesuatu dengan benar secara otomatis. Pada tahap adaptasi, praktek atau tindakan sudah berkembang dengan baik. ${ }^{6}$ 


\section{SIMPULAN}

Pada penelitian yang dilaksanakan pada mahasiswa Fakultas Kedokteran umum tahap profesi dan mahasiswa program studi keperawatan dapat disimpulkan sebagai berikut:

Dalam hal pengetahuan, sebagian besar mahasiswa Fakultas Kedokteran tahap profesi dan mahasiswa program studi keperawatan sudah mempunyai tingkat pengetahuan yang baik sekali. Dalam hal sikap, sebagian besar mahasiswa Fakultas Kedok-teran tahap profesi dan program studi keperawatan sudah mempunyai sikap yang baik. Dalam hal tindakan, sebagian besar mahasiswa Fakultas Kedokteran tahap profesi sudah mempunyai tindakan yang cukup sedangkan pada mahasiswa program studi keperawatan mempunyai tindakan yang baik. Kategori ini didapat dari hasil perhitungan distribusi frekuensi.

\section{DAFTAR PUSTAKA}

1. Djuanda A. HIV \& AIDS, cetakan kelima, 5th Ed. Jakarta: Balai Penerbit FKUI, 2011; p.427.

2. Tambajong EH. Laboratorium Patologi Anatomi. Manado: Fakultas Kedokteran Universitas Sam Ratulangi, 1993.

3. Nasronudin. HIV/AIDS Pendekatan Biologi Molekuler, Klinis, dan Sosial. Surabaya: Airlangga University Press, 2007.

4. Konsep perilaku pengertian perilaku bentuk perilaku'dan domain [homepage on the Internet]. Nodate [cited 2011 Nov 14]. Available from: http://www.Infoskripsi.com

5. Bakhtiar. Pengertian pengetahuan tinjauan pustaka [homepage on the Internet]. 2004 [cited 2011 Nov 14]. Available from:

http://respository.usu.ac.id/bitstream/ch apterII/pdf

6. Notoatmodjo S. Ilmu Kesehatan Masyarakat. Jakarta: Rineka Cipta, 2003. 